\title{
Evaluation of Capillaries with Different Inner Coatings for DNA Analysis using Dilute Polymer Solutions by Capillary Electrophoresis
}

\author{
Patrícia de F. M. Eugênio and Emanuel Carrilho*
}

Instituto de Química de São Carlos, Universidade de São Paulo, Av. Trabalhador São-Carlense, 400, 13560-970, São Carlos-SP, Brazil

\begin{abstract}
No presente trabalho, três colunas capilares, uma sem recobrimento interno e duas com recobrimentos internos diferentes foram utilizadas na separação de fragmentos de DNA: poli(vinil álcool) (PVA) e poli(dimetilacrilamida) (PDMA) - ambos de recobrimento covalente - foram comparados para a separação de DNA utilizando soluções poliméricas. As separações foram realizadas usando hidroxietilcelulose (HEC) (90-105 kDa) nas concentrações entre 0,00 e 2,00\% $\mathrm{m} / \mathrm{v}$. Os resultados indicaram que a eficiência de separação foi maior no capilar de PVA do que no de PDMA, em todas as concentrações de HEC testadas. Ainda, uma resolução superior também foi observada com o capilar de PVA, já que com o capilar de PDMA o formato dos picos não se mostrou reprodutível quando corridas subseqüentes foram realizadas. Contrariamente ao relatado na literatura, nenhuma separação foi conseguida com o capilar sem revestimento interno.
\end{abstract}

In this work three capillary columns, one with uncoated inner wall and two with covalentlybound internal coatings - poly(vinyl alcohol) (PVA) and poly(dimethylacrylamide) (PDMA) - both covalently covered - were used to separate DNA fragments and compared to DNA separation using replaceable polymer solutions. The separations were performed using hydroxyethylcellulose (HEC) (90-105 kDa) in concentrations ranging from 0.00 to $2.00 \% \mathrm{~m} / \mathrm{v}$. The results indicated that the separation efficiency was higher in the PVA capillary than in the PDMA in all evaluated concentrations of HEC. In addition, higher resolution was also observed in PVA-coated capillary since in PDMA the shape of the peaks was not reproducible when subsequent runs were performed. Contrary to what has previously been reported in the literature, no reasonable separation was possible in bare fused silica.

Keywords: DNA separation, capillary coating, laser-induced fluorescence, PDMA, PVA

\section{Introduction}

Capillary electrophoresis (CE) is a separation technique widely used for separation of biological macromolecules. It offers great advantages over slab-gel electrophoresis (SGE) - shorter analysis time, smaller quantity of sample, greater efficiency of separation, and easier automation. ${ }^{1,2}$

The first attempts to apply CE to DNA separations were carried out in capillaries filled with cross-linked gels, like polyacrylamide ${ }^{3-5}$ Later on, some polymeric solutions were used, known as dynamic or physical gels, which are easily prepared and introduced into the capillary, thus enabling its renewal after each analysis and the use of a single capillary for many separations, without any problem with the subsequent separations. ${ }^{6}$

\footnotetext{
*e-mail: emanuel@iqsc.usp.br
}

DNA migration mechanisms in polymeric matrices

The Ogston and the reptation models were first proposed to explain DNA migration in slab gels, but they have also shown themselves suitable for polymeric solutions. ${ }^{7}$ According to the Ogston theory, the DNA fragment keeps a spherical and rigid conformation of radius $\mathrm{Rg}$. This particle moves across a random net formed by the gel fibers. These fibers form pores with average size $\xi$, which is a function of the polymeric concentration. The smaller molecules migrate faster than the bigger ones, as they have access to a greater number of pores of their size. The Ogston mechanism describes satisfactorily the mobility of small DNA fragments in low electric fields and in low gel concentrations. ${ }^{8-12}$

When a larger DNA fragment crosses a polymeric network with $\xi<<\operatorname{Rg}$, it undergoes a distortion so that it still passes across the dynamic pore; therefore, there is no further agreement with the Ogston theory. The reptation system 
explains this fact, since it describes the DNA as a molecule with an undisturbed spiral conformation, which moves like a snake, "crawling" along the "tubes" formed by the polymeric matrix. The electrophoretic mobility is inversely proportional to the solute size. This theory is applicable especially to separations carried out in low electrical fields. ${ }^{12-15}$

In high electrical fields, such as those typically applied for capillary electrophoresis separations, a modified reptation model is employed to explain the migration of the solute over the matrix. This model explains that the electrical field stretches the DNA molecules, and then all the fragments are able to migrate at the same time across the gel. Because of this, the discrimination of the solute by size no longer exists, so electrophoretic separation ability based on molecular size is lost. ${ }^{13,16}$

The separation of DNA fragments in polymers below the entanglement threshold ( $\mathrm{c}^{*}$ ) was first accomplished by Barron et al. , $^{17,18}$ proving that the formation of a physical net by the polymer molecules is not essential for the solute separation. This fact showed that the Ogston and the reptation theories are not enough to explain the DNA migration mechanism in physical gels. Barron et al. ${ }^{1}$ then proposed the "transient entanglement coupling" theory - the DNA molecules interact with the gel fibers through collisions during electrophoretic separation, forcing the DNA to drag these fibers. The more fibers one fragment drags, the lower is its mobility over time; and the larger the fragment, the greater is the probability of its interaction with the polymers in solution. ${ }^{1,17-19}$

\section{Capillary inner coatings}

For electrophoretic separations of DNA in polymeric solutions, it is common to use internally coated capillaries in order to suppress the electroosmotic flow (EOF) and hinder DNA interaction with the capillary wall, improving the separation. ${ }^{20-24}$ We tested three different capillaries in this study. One of them was recovered with PVA, a highly hydrophilic polymer covalently bound to the capillary surface. This column was used as a reference, since it has already provided good results for DNA separations with HEC. ${ }^{25}$ As an alternative capillary coating, we used another covalently bound coating of PDMA, a polymer with hydrophobic characteristics. ${ }^{26}$ Based on successful results acquired with uncoated capillaries, described by Barron et al., ${ }^{1}$ we also used this kind of capillary in our experiments for comparison.

\section{Experimental}

\section{Instrumentation}

The capillary electrophoresis apparatus employed for all analysis was a P/ACE 5000 System from Beckman (Fullerton, CA, USA), equipped with a laser-induced fluorescence (LIF) detection unit, and controlled by an IBM-compatible PC with System GOLD 32 Software (Beckman) for analysis and data acquisition. Analyte excitation was carried out with a $3 \mathrm{~mW}$ Argon-ion laser $\left(\lambda_{\text {exc }}=488 \mathrm{~nm}\right)$. A $488 \mathrm{~nm}$ laser line rejection filter was placed in the light path to block the scattered laser radiation, together with a $20 \mathrm{~nm}$ bandwidth filter centered at $520 \mathrm{~nm}$ for selection of the fluorescent light. All separations were carried out by the application of a $200 \mathrm{~V} \mathrm{~cm}^{-1}$ electrical field with reversed polarity (i.e., the capillary inlet was the cathode and the capillary outlet was the anode) because of the suppressed EOF. For the uncoated capillaries, the polarity was switched to normal polarity, that is, the cathode was in the capillary outlet and a cathodic EOF was observed. The samples were electrokinetically (EK) injected at $200 \mathrm{~V} \mathrm{~cm}^{-1}$ for $10 \mathrm{~s}$.

\section{Reagents and solutions}

The reagents used for the preparation of buffer solutions were $N$-tris(hydroxymethyl)methyl-3aminopropanesulfonic acid (TAPS) purchased from Sigma (St Louis, MO, U.S.A.), tetrapentylamonium bromide - $\mathrm{NPe}_{4} \mathrm{Br}$ (Acros organics, New Jersey, USA), EDTA, (Mallinckrodt, St Louis, MO, USA), and sodium hydroxide (Synth, Diadema, SP, Brazil). The polymeric matrix used for the separation of the DNA ladder was HEC (Fluka, Buchs, Switzerland), with a number-average molecular mass of 90-105 kDa. The DNA sample used in the experiments was a $1000 \mu \mathrm{g} \mathrm{mL}^{-1} \mathrm{DNA}$ ladder of $1 \mathrm{kbp}$, from Gibco (Carlsbad, CA, USA), with 22 restriction fragments ranging from $75 \mathrm{bp}$ to $12 \mathrm{kbp}$. To stain the DNA fragments, we used the dimeric intercalator TOTO ${ }^{\circ}-1$ iodide $\left(\lambda_{\max }=514 \mathrm{~nm}\right)$, from Molecular Probes (Eugene, OR, USA), following the procedure already adopted in our laboratory. ${ }^{27} \mathrm{~A} 1 \mathrm{mmol} \mathrm{L}{ }^{-1}$ stock solution of TOTO-1 intercalator was prepared in DMSO. The buffer solution used in the analysis was $\mathrm{NPe}_{4}$-TAPS $\left(50 \mathrm{mmol} \mathrm{L}^{-1} \mathrm{NPe}_{4}\right.$, $50 \mathrm{mmol} \mathrm{L}^{-1}$ TAPS, $\left.2 \mathrm{mmol} \mathrm{L}^{-1} \mathrm{EDTA}\right) \mathrm{pH}$ 8.5. The solution was filtered with pore size of $0.22 \mu \mathrm{m}$ (Millipore, Bedford, MA, USA) before use. The following concentrations of HEC solutions were prepared from a 2.0\% HEC stock solution: $0.00125,0.00250,0.00500,0.010,0.020,0.040$, $0.080,0.010,0.015,0.25,0.5,1.0,1.5$, and $1.8 \%$. These solutions were all diluted in the pre-filtered buffer solution. All polymer solutions were homogenized by a magnetic agitator at minimal speed to avoid the breakage of fibers of the polymer. 


\section{Sample preparation}

The DNA ladder was intercalated with intercalator by mixing $10 \mu \mathrm{g}$ of a DNA (1000 $\mathrm{g} \mathrm{mL}^{-1}$ solution) with $1 \mu \mathrm{L}$ of $0.1 \mathrm{mmol} \mathrm{L}^{-1}$ intercalator work solution, which was prepared by the 1:10 dilution of the initial stock solution. The aliquots of DNA were added to the intercalator in order to avoid the precipitation of the DNA fragments. Each vial with the complexes was slightly shaken and then kept in the dark for $1 \mathrm{~h}$, to guarantee the efficiency of the intercalation process. Even after the intercalation process the samples were kept in the dark. ${ }^{27-33}$

\section{Capillaries}

The bare fused silica (Polymicro Technologies, Phoenix, AZ, USA) and the PVA coated capillaries (Agilent Technologies, Waldbronn, Germany) were $75 \mu \mathrm{m}$ i.d. and $27 \mathrm{~cm}$ in length (20 cm effective length). The PDMA coated capillary was $50 \mu \mathrm{m}$ i.d. and $27 \mathrm{~cm}$ in length $(20 \mathrm{~cm}$ effective length and was coated with PDMA in house ${ }^{26}$ by adaptation of an earlier published method. ${ }^{34}$ Basically, new capillaries were cleaned with acetone (10 min), $1 \mathrm{~mol} \mathrm{~L}^{-1}$ $\mathrm{NaOH}$ (30 min), $0.1 \mathrm{~mol} \mathrm{~L}^{-1} \mathrm{HCl}$ (10 min), and finally washed with water (10 min). After these washing steps, the capillaries were silanized overnight at room temperature. The coating procedure started with the polymerization of dimethylacrylamide (DMA) by radical initiators ammonium persulfate and trimethylethylenediamine. Unreacted monomers were washed with water.

The coated capillaries were pre-conditioned first by washing them with deionized water (Mili-Q, Millipore, Bedford, MA, USA) for $20 \mathrm{~min}$ and then with the run buffer for another $20 \mathrm{~min}$. After pre-conditioning, the columns were filled with the polymeric matrix with a microsyringe connected to the capillary by a Teflon microtube (350 $\mu \mathrm{m}$ i.d.). A $20 \mathrm{~min}$ pre-run was carried out to equilibrate the column before the sample injection. The uncoated capillary was conditioned for $10 \mathrm{~min}$ with $1 \mathrm{~mol} \mathrm{~L}-1 \mathrm{NaOH}, 10$ min with $0.1 \mathrm{~mol} \mathrm{~L}^{-1} \mathrm{NaOH}, 10 \mathrm{~min}$ with deionized water and $15 \mathrm{~min}$ with the polymeric matrix, before each separation.

\section{Results and Discussion}

\section{PVA coated capillary}

We used the PVA coated capillary as the standard for comparison since many of the best DNA separations reported were obtained using this kind of coated capillary, but using different polymer solutions. Figure 1 illustrates the electropherograms obtained for the separation of the $1 \mathrm{kbp}$ DNA ladder in the following HEC concentrations: $0.0,0.0025,0.010,0.020,0.040,0.080,0.10,0.20,0.25$, $0.50,1.0,1.5,1.8$ and $2.0 \%$.

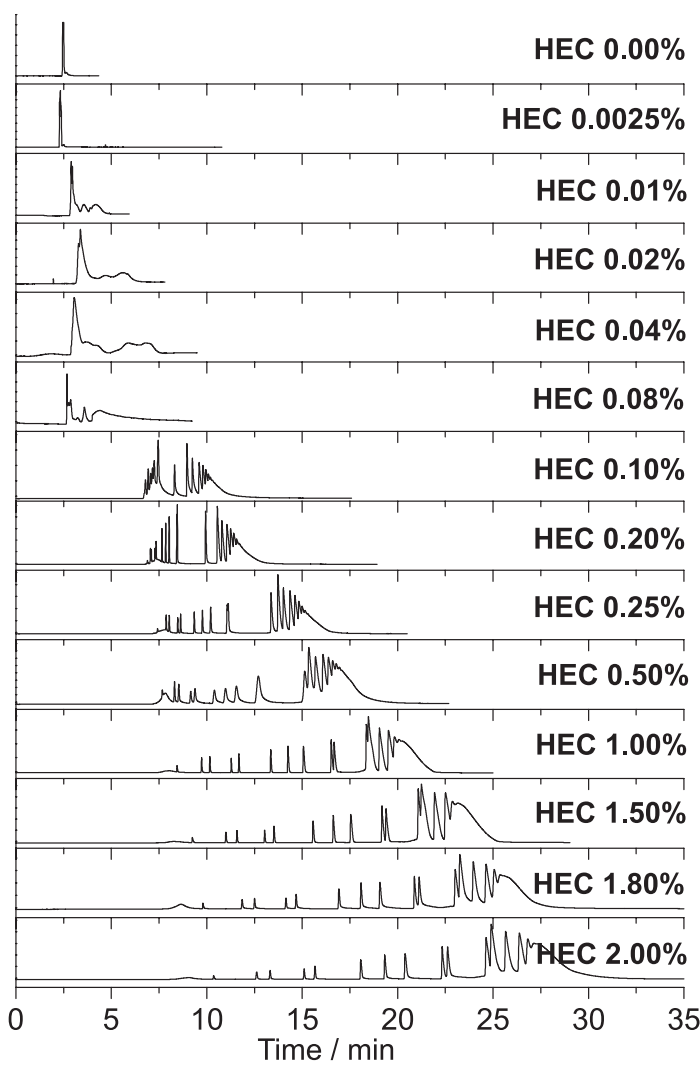

Figure 1. Electrophoretic separation of the 1kbp DNA ladder fragments intercalated with TOTO ${ }^{\circledR}-1$ iodide in PVA column using different HEC concentrations, as indicated in the graph. The buffer solution was $50 \mathrm{mmol} \mathrm{L}^{-1} \mathrm{NPe}_{4}, 50 \mathrm{mmol} \mathrm{L}^{-1}$ TAPS, 2 mmol L-1 EDTA, pH 8.5. The capillary was $27 \mathrm{~cm}$ long ( $20 \mathrm{~cm}$ effective length) and $75 \mu \mathrm{m}$ i.d. The electric field was $200 \mathrm{~V} \mathrm{~cm}^{-1}$ for both separation and injection $(10 \mathrm{~s})$. The detector was an LIF with excitation at $488 \mathrm{~nm}$ and emission at $520 \mathrm{~nm}$.

It is possible to note that in the first two runs, i.e., the one with buffer solution and the other with $0.0025 \%$ HEC, no fragment separation was achieved. Also, it can be seen that no DNA peak delay occurred in the $0.0025 \%$ matrix, comparing with the peak of the electropherogram in free buffer solution. In the HEC concentrations between 0.010 and $0.080 \%$, it is possible to observe the start of the separation of fragments since some of them have undergone an increase in migration time. However, it is still not possible to identify which fragments were separated. Moreover, the largest peak of each electropherogram is still in line with the corresponding peak of the run carried out with the buffer solution, indicating no retardation in the migration mechanism. From $0.10 \%$ onwards, it was possible to obtain an improved peak separation, although this concentration was still below the entanglement 
threshold $\left(\mathrm{c}^{*}\right)$ for the polymer used (HEC), which is $0.37 \% .^{1}$ This result proves that the reptation and the Ogston theories are not, in fact, sufficient to explain exactly the mechanism of DNA separation in this kind of polymeric solutions, since the polymer cannot form pores if its concentration is below $\mathrm{c}^{*}$. The transient entanglement coupling theory, proposed by Barron et al.,$^{18}$ on the other hand, is a very reasonable explanation for this data. For HEC concentrations between 0.1 and $2.0 \%$, it was possible to obtain good peak symmetry and also a regularity of peak separations in each electropherogram. In other words, the spacing between the corresponding peaks in each run has increased progressively according to HEC concentration. As the polymer concentration increased, the spacing between peaks also increased, improving the resolution of the separations. Therefore, the mobility of each fragment diminished proportionally with the increase of HEC concentration. The graphs of migration time of the DNA fragments versus the number of base pairs (bp) are illustrated in Figure 2, and they were plotted for the separations carried out in HEC concentrations from 0.1 to $2.0 \%$, whose results were the most consistent.

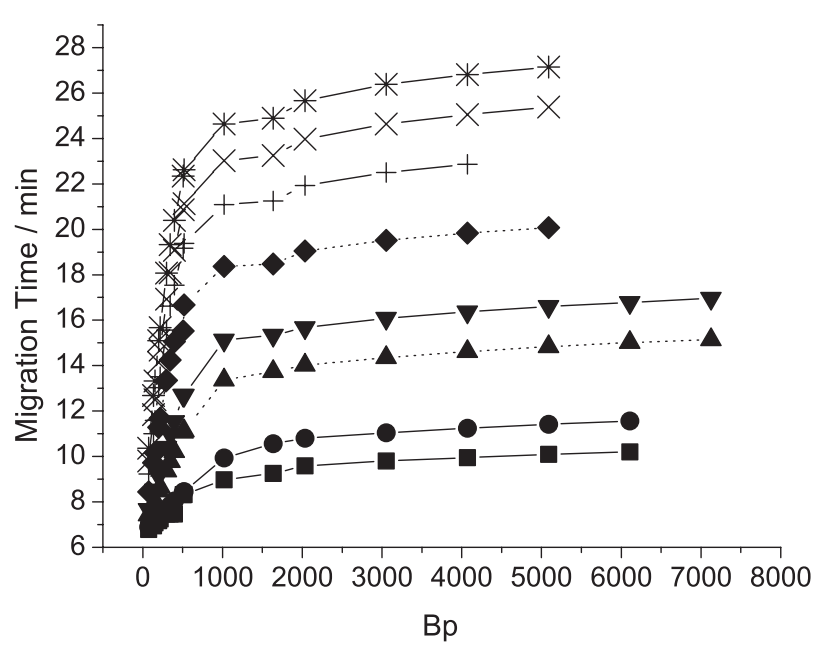

Figure 2. Plot of migration time versus size of DNA, calculated for the electropherograms from Figure 1 for evaluation of the mechanisms of DNA migration. Symbols: - - HEC $0.10 \%$; - - HEC $0.20 \% ; \cdots \boldsymbol{\Delta} \cdots$ HEC $0.25 \%$; - - - HEC $0.50 \% ; \cdots \bullet$ HEC $1.00 \%$; -+- HEC $1.50 \%$; $-\times$ - HEC $1.80 \%$; - *- HEC $2.00 \%$.

With respect to the number of peaks observed, it is evident that the most diluted solutions provided greater separation power. The analysis in $0.25 \% \mathrm{HEC}$, in particular, has been more efficient because it was possible to see the beginning of separation of the peaks of very closely separated peaks such as fragments 506 and $517 \mathrm{bp}$. A better resolution of the peaks related to smaller fragments was obtained, however, in more concentrated polymers. This occurred because in lower concentration matrices, they do not entangle and therefore do not form pores for the separation of small fragments. At higher concentrations, the matrix forms dynamic pores and allows separation of small fragments according to the Ogston mechanism. On the other hand, a lower concentration of HEC allowed for better sieving of large DNA fragments that undergo the transient entanglement mechanism.

The mobility log graphs of $\log$ of mobility of the DNA fragments versus their bp log number were plotted for the separations carried out in HEC concentrations between 0.1 and $2.0 \%$, and they are illustrated in Figure 3. In this way, it is thus possible to confirm the most important mechanisms of DNA migration in polymeric solutions. In general, all curves follow the same profile and can be divided into two regimes according to the DNA size. For the fragments up to $500 \mathrm{bp}$, the graphs follow a decreasing relationship of mobility and DNA size, showing that the gel causes a greater delay effect in smaller fragments. Higher polymer concentrations guarantee a higher spacing (greater selectivity) between these peaks (i.e., smaller fragments), providing good resolution.

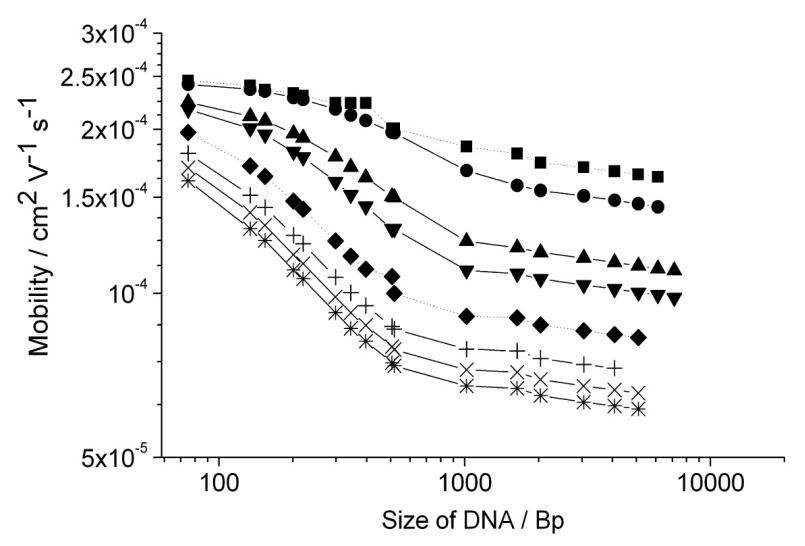

Figure 3. Plot of mobility versus number of bp calculated from data extracted from Figure 2. Symbols: $\cdots \square$... HEC $0.10 \%$; - - HEC $0.20 \%$; $-\boldsymbol{\Delta}-$ HEC $0.25 \% ;-\boldsymbol{\nabla}-$ HEC $0.50 \% ; \cdots-\cdots$ HEC $1.00 \%$; - +- HEC $1.50 \% ;-\times-$ HEC $1.80 \%$; - *-HEC $2.00 \%$. The left portion of the curves is governed by the Ogston theory while the central part is regulated by the reptation mechanism of migration.

As in the case of fragments larger than $1000 \mathrm{bp}$, the differences in mobility between the fragments have an almost constant value, which is verified by the electropherograms with collapsed peaks at the end of the separation. In such cases, it is possible to visualize just a partial separation of the larger fragments.

Both cases could be explained by the Ogston and the reptation theories, respectively. The Ogston model considers the polymeric environment as a sieve with pore sizes dependent on polymer concentration. More concentrated gels possess smaller pores, which improve 
the separation of the smaller fragments. However, when larger molecules encounter these small pores, they are not able to cross them, according to this theory, because they are treated as non-deformable spheres. When the Ogston mechanism fails, the reptation theory takes its place to elucidate how the bigger fragments keep on migrating across the gel. ${ }^{11,12}$ The DNA that is larger than the average pore size at a given polymer concentration experiences a migration regime where the DNA stretches and slide through the pores like a snake.

\section{PDMA coated capillary}

The PDMA capillary was manufactured in our laboratory ${ }^{26}$ according to a previously published procedure ${ }^{34}$ and, to the best of our knowledge, this is the first application of this coating and HEC polymer solutions for the separation of DNA molecules. The HEC concentrations selected for this study were $0.15,0.25,0.50,1.00,1.50$ and $1.80 \%$ because this range of concentration has shown good results for separations in the PVA capillary. The electropherograms obtained in the separation of the $1 \mathrm{kbp}$ DNA ladder with this capillary are presented in Figure 4.

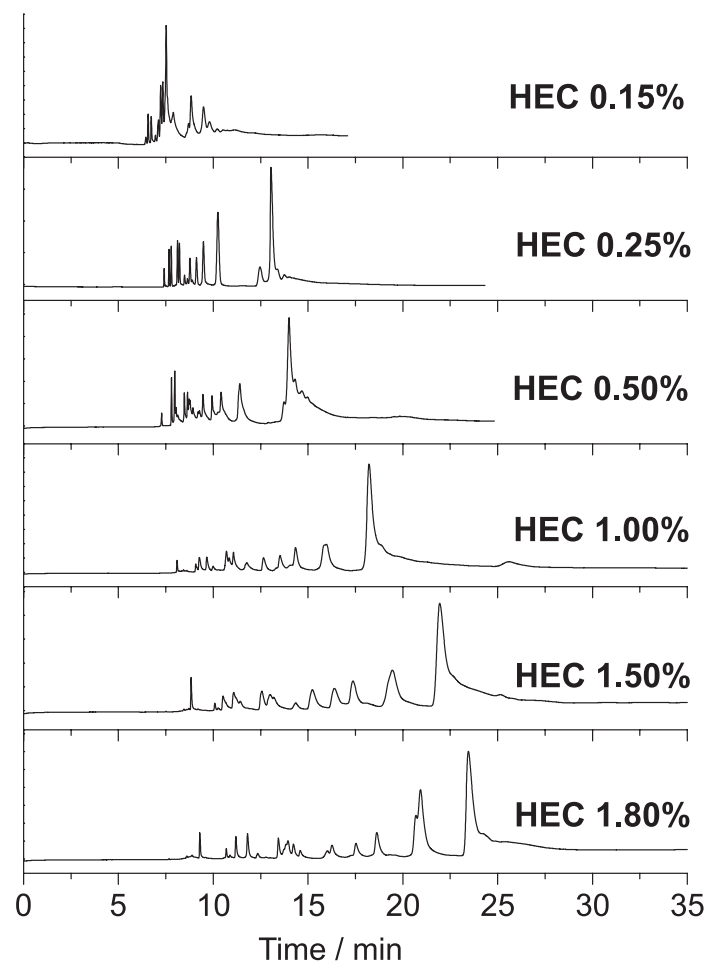

Figure 4. Electrophoretic separation of the $1 \mathrm{kbp}$ DNA ladder fragments intercalated with TOTO $^{\circledR}-1$ iodide in PDMA column with different HEC concentrations, as indicated. The buffer solution was $50 \mathrm{mmol} \mathrm{L}^{-1}$ $\mathrm{NPe}_{4}, 50 \mathrm{mmol} \mathrm{L}^{-1}$ TAPS, 2 mmol L ${ }^{-1}$ EDTA, pH 8.5. The capillary was $27 \mathrm{~cm}$ long ( $20 \mathrm{~cm}$ effective length) and $50 \mu \mathrm{m}$ i.d. The electric field was $200 \mathrm{~V} \mathrm{~cm}^{-1}$ for both separation and injection $(10 \mathrm{~s})$. The detector was an LIF with excitation at $488 \mathrm{~nm}$ and emission at $520 \mathrm{~nm}$.
The results obtained with the PDMA capillary showed that these separations did not present the same peak symmetry as that obtained in the PVA capillaries. Additionally, the shape and the number of peaks were different in each matrix concentration used, mainly with $0.15,0.25$ and $0.50 \%$ HEC. This hindered identification of the size of DNA fragments. Nevertheless, a sequence of three peaks was identified, related to the fragments of 298 , 344 and 396 bp, followed by the pair 506/517 bp. Figure 5 compares the electropherograms carried out in the PVA and PDMA capillaries, at the same polymer concentrations, in which runs in 0.25 and $1.0 \%$ HEC were illustrated. It can be noted that in both HEC concentrations the peaks of the fragments separated in the PDMA capillary show a higher mobility, if compared with the respective peaks in the electropherograms obtained in the PVA capillary.

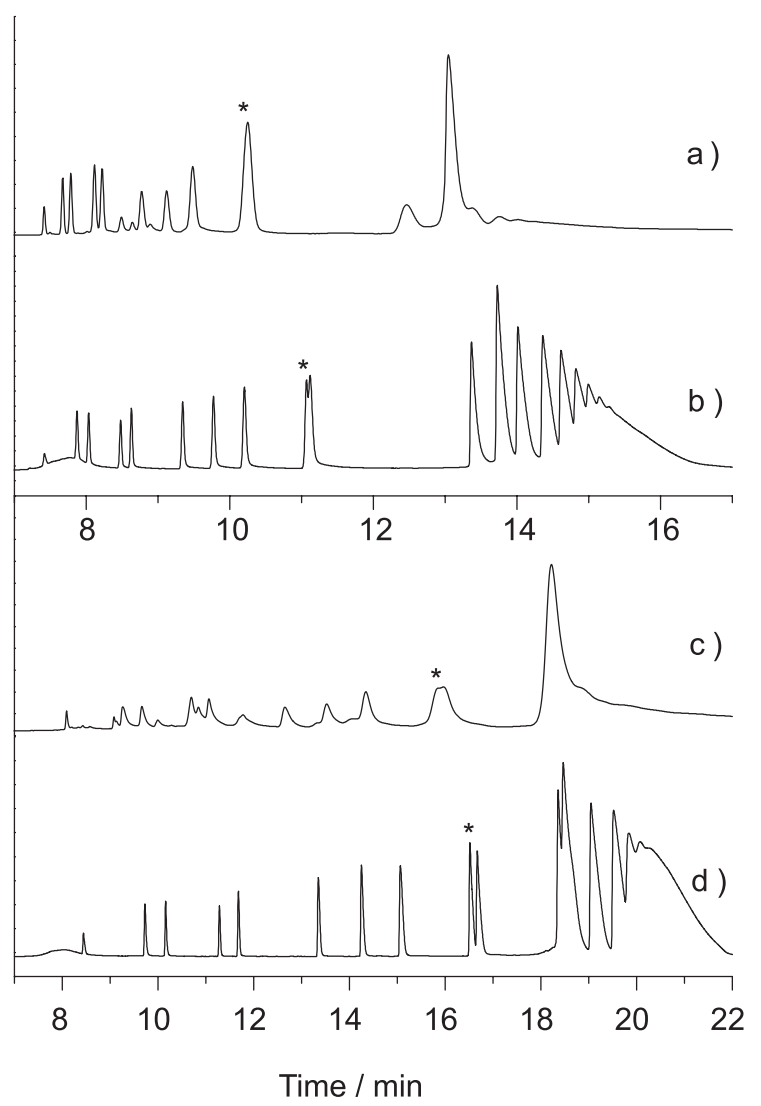

Figure 5. Close comparison of the DNA separation in two selected concentrations of HEC in two different coated capillaries. The concentration of HEC was $0.25 \%$ in A) PDMA, and B) PVA, and the concentration of HEC was $1.00 \%$ in C) PDMA, and D) PVA. * Denotes the pair of peaks with 506 and 517 bp. Data extracted from Figures 1 and 4 for PDMA and PVA, respctively.

From these data it is not possible to deduce the probable reasons for this increase in mobility. Since the capillary inner coating was made in the laboratory, the expectation was that it could produce a considerable EOF 
when compared to the PVA capillary. If any considerable amount of EOF was present, a decrease in mobility would be observed. Therefore, the data show that any EOF in the PDMA capillary is still less significant than the EOF of the PVA capillary. So it cannot be stated that the cause of the distorted peaks in the separations in the PDMA capillary is a consequence of the electroosmotic flow. Furthermore, in terms of separation efficiency, it is possible to observe clearly that the separations with the PVA capillary were the best ones, in any HEC concentration used. A different number of fragments was observed, and the symmetry of the peaks was also very good. Taking into account the electropherograms in $1.0 \%$ HEC, it is possible to see that the pattern of separation in the PDMA capillary is completely different and the separation efficiency is much less than that presented by the PVA capillary.

One of the possible causes of these results may be the internal diameter of the capillary used, which is $50 \mu \mathrm{m}$. The smaller the internal diameter of the capillary used, the greater the proximity of the analytes to the capillary wall. A possible interaction between the fragments and the wall may have caused the peak deformation. Another cause may be the chemical incompatibility between the hydrophilic HEC and the hydrophobic PDMA. Because of this, the polymeric solution used may not have been adsorbed in a uniform way to the internal surface of the capillary, causing the loss of efficiency in the separations. In other words, the PDMA polymer has methyl groups that are hydrophobic, while the PVA polymers, as well as HEC, are hydroxylated polymers and therefore highly hydrophilic. These differences in hydrophilicity may have hindered the formation of a uniform gel coating on the inner surface of the PDMA capillary, resulting in poor separation of DNA fragments.

With respect to the reptation and the Ogston mechanisms, despite observing the aforementioned differences in capillary performance, the migration of the fragments showed similar behavior in both cases. This comparison can be more clearly seen in Figure 6, where two curves of mobility $\log$ versus bp number log were plotted for both columns and $0.25 \%$ HEC. As in the PVA capillary, the smaller fragments underwent a considerably higher change in mobilities in the PDMA column but still followed the Ogston mechanism. Regarding the larger fragments, it was not possible to identify the fragments of the $1 \mathrm{kbp}$ DNA ladder in the separations carried out in the PDMA capillary. In fact, all the DNA fragments larger than $1000 \mathrm{bp}$ are grouped in only two peaks, as can be seen in Figure 4. The fact that the migration mechanisms were conserved in both coated columns makes the results obtained even more intriguing, in terms of peak shape and peak symmetry in the PDMA. Reasons for this remain unknown and should be further investigated.

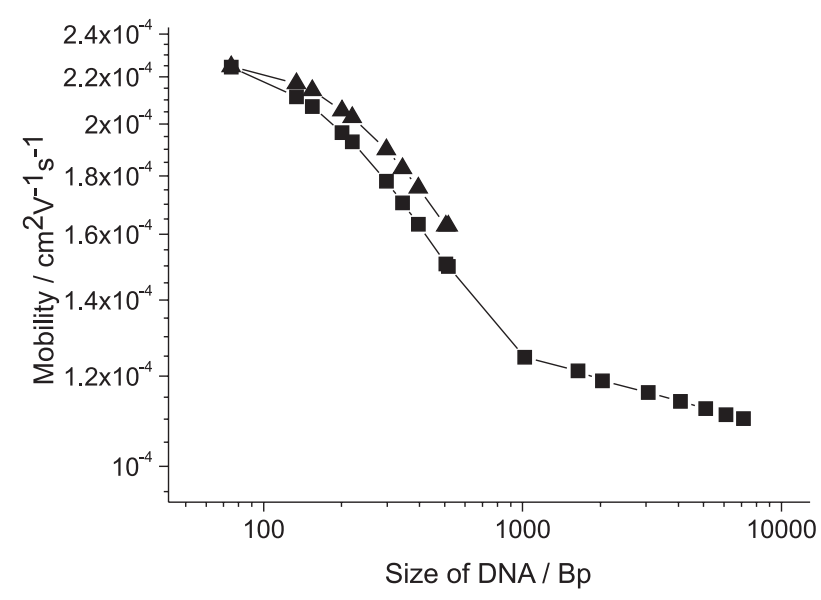

Figure 6. Plot of mobility versus number of bp for the separations carried out with $0.25 \%$ HEC, in both PVA (- - ) and PDMA (- $\left.\boldsymbol{\Delta}_{-}\right)$capillaries. Data extracted from Figures 1 and 4, respectively.

\section{Uncoated capillaries}

The separations obtained with the uncoated capillary were the ones presenting the worst results. In these separations it was possible to visualize, at most, three peaks without any reasonable resolution. In these electropherograms it was not possible to attribute any size to the fragments of the DNA ladder. Three electropherograms are illustrated in Figure 7 for the visualization of separation behavior.

With increasing HEC concentration, the only consequence was migration delay for the main peak,

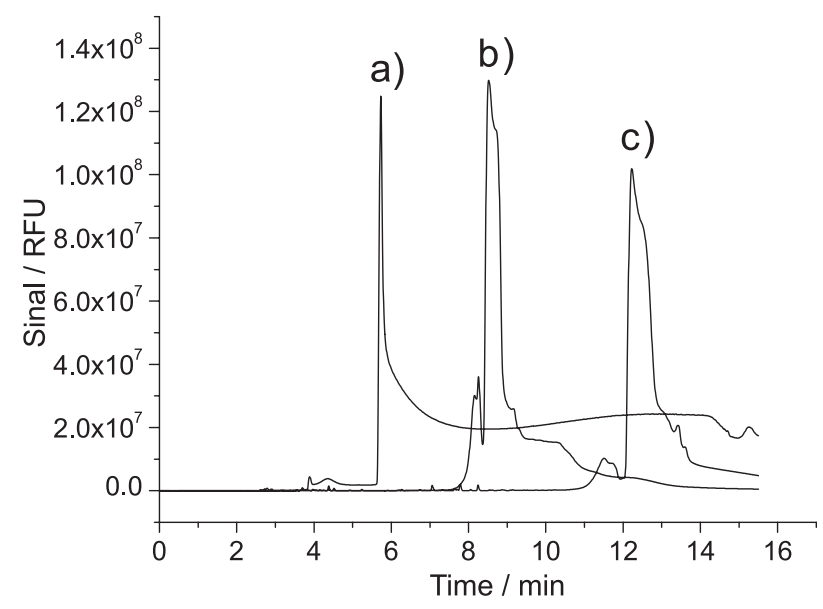

Figure 7. Electrophoretic separation of the $1 \mathrm{kbp}$ DNA ladder fragments intercalated with $\mathrm{TOTO} \AA-1$ iodide in a bare fused silica capillary with different HEC concentrations: a) $0.00 \%$, b) $0.10 \%$, and c) $0.15 \%$. The buffer solution was $50 \mathrm{mmol} \mathrm{L}^{-1} \mathrm{NPe}_{4}, 50 \mathrm{mmol} \mathrm{L}^{-1} \mathrm{TAPS}, 2 \mathrm{mmol} \mathrm{L}^{-1}$ EDTA, pH 8.5. The capillary was uncoated and was $27 \mathrm{~cm}$ long $(7 \mathrm{~cm}$ effective length), $75 \mu \mathrm{m}$ i.d. The electric field was $200 \mathrm{~V} \mathrm{~cm}^{-1}$ for both separation and injection (10 s). The detector was an LIF with excitation at $488 \mathrm{~nm}$ and emission at $520 \mathrm{~nm}$ 
which is in accordance with the Ogston theory. The resolution of the fragments with different sizes, however, was not possible in this capillary, and it was not possible to reproduce the historical data from literature. ${ }^{1,17-19}$ The behavior expected in this capillary was first the arrival of the larger fragments at the detector, followed by the smaller ones. With the presence of electroosmotic flow, the bigger molecules are carried more easily to the detector, because of their slower mobilities. ${ }^{1}$ With the increase in HEC concentration, a proportional delay in migration time would be expected, because this increase reduces the electroosmotic flow by the increase in viscosity of the solution and in the number of obstacles (polymer fibers) against the migration of DNA molecules. It was possible to observe a delay of the fragments, however without peak separation. These results prove again that the HEC polymer solutions were, in all cases, producing data in the expected manner, but satisfactory selectivity and efficiency were not always obtained.

Some possible causes for the differences in our results with the uncoated capillary, in comparison with the data from literature, ${ }^{1,17-19}$ can be mentioned here. The dimensions of the capillary used by Barron et al. ${ }^{1}$ were different from ours $(51 \mu \mathrm{m}$ i.d. and $50 \mathrm{~cm}$ in length, with $35 \mathrm{~cm}$ effective length in Barron's work). Capillaries with thinner diameters can provide a better resolution in separation and more efficient heat dissipation. The longer the capillary, the better the selectivity of the analysis, and the probability of the molecules to drag the fibers increases, reducing their mobilities. Moreover, our analyses were accomplished in an instrument with a laser-induced fluorescence (LIF) detection unit, thus requiring the use of an intercalator for the DNA fragments. This intercalator modifies DNA structure, reducing its flexibility. Since the basis of DNA separation in diluted polymers (the "transient entanglement coupling" theory) is the interaction of DNA molecules with the gel fibers, ${ }^{1,17-19}$ this structure modification in DNA may also change the separation mechanism.

\section{Conclusions}

Under the circumstances evaluated in this article, it was possible to verify that the separations carried out in the PVA capillary were the best in all HEC concentrations, presenting well-defined and spaced peaks for HEC concentrations above $0.10 \%$. At $0.25 \%$, the HEC solution separated the greatest number of fragments, which is relevant for DNA sizing analysis. The most diluted solutions were better able to separate the largest fragments, while the most concentrated ones produced a higher resolution for the smallest fragments. These results are all in accordance with the theoretical models described previously. With the PDMA capillary, the peaks of DNA fragments did not show similar resolution and the separations were not efficient. However, the expectation that this column would not be efficient owing to an inferior EOF suppression did not in fact happen, and the PDMA column can be further optimized for proteins, peptides, and even DNA, with polymers other than HEC. The incompatibility or the difference of hydrophilicity between PDMA and HEC may have been the main reason for the poor separation. Unfortunately, the bare fused-silica capillary was not effective for the separation of DNA fragments presented in the size ladder we used, and in the experimental conditions here specified.

\section{Acknowledgements}

The authors are grateful to Fundação de Amparo à Pesquisa do Estado de São Paulo (FAPESP) for financial support, under grant number 98/12385-2, and to the Conselho Nacional de Desenvolvimento Científico e Tecnológico (CNPq), Programa Institucional de Bolsas de Iniciação Científica (PIBIC/IQSC-USP) for a scholarship (P.F.M.E.) and a fellowship (E.C.).

\section{References}

1. Barron, A. E.; Sunada, W. M.; Blanch, H. W.; Electrophoresis 1995, 16, 64 .

2. Chiari, M.; Cretich, M.; Horvath, J.; Electrophoresis 2000, 21 , 1521.

3. Baba, Y.; Matsuura, T.; Wakamoto, K.; Morita, Y.; Nishitsu, Y.; Tsuhako, M.; Anal. Chem. 1992, 64, 1221.

4. Cohen, A. S.; Najarian, D. R.; Karger, B. L.; J. Chromatogr. 1990, 516, 49.

5. Cohen, A. S.; Karger, B. L.; J. Chromatogr. 1987, 397, 409.

6. Ruiz-Martinez, M. C.; Berka, J.; Belenkii, A.; Foret, F.; Miller, A. W.; Karger, B. L.; Anal. Chem. 1993, 65, 2851.

7. Grossman, P. D.; soane, d. S.; J. Chromatogr. 1991, 559, 257.

8. Rodbard, D.; Chrambach, A.; Proc. Nat1. Acad. Sci. USA 1970, 65, 970 .

9. Ogston, A. G.; Trans. Faraday Soc. 1958, 54, 1754.

10. Chrambach, A.; Rodbard, D.; Science 1971, 172, 440.

11. Labrie, J.; Mercier, J.; Slater, G. W.; Electrophoresis 2000, 21, 823.

12. Heller, C.; Electrophoresis 1999, 20, 1962.

13. Slater, G. W.; Rousseau, J.; Noolandi, J.; Turmel, C.; Lalande, M.; Biopolymers 1988, 27, 509.

14. Lerman, L. S.; Frisch, H. L.; Biopolymers 1982, 21, 995.

15. Doi, M.; Edwards, S. F.; J. Chem. Soc. Faraday Trans. II 1978, 74, 1789. 
16. Lumpkin, O. J.; Dejardin, P.; Zimm, B. H.; Biopolymers 1985, $24,1573$.

17. Barron, A. E.; Soane, D. S.; Blanch, H. W.; J. Chromatogr. 1993, 652, 3.

18. Barron, A. E.; Blanch, H. W.; Soane, D. S.; Electrophoresis 1993, 15, 597.

19. Barron, A. E.; Sunada, W. M.; Blanch, H. W.; Electrophoresis 1996, 17, 744.

20. Lambert, W. J.; Middleton, D. L.; Anal. Chem. 1990, 62, 1585.

21. Moseley, M. A.; Deterding, L. J.; Tomer, K. B.; Jorgensos, J. W.; Anal. Chem. 1991, 63, 109.

22. Reijenga, J. C.; Aben, G. V. A.; Verheggen, T. P. E. M.; Everaerts, F. M.; J. Chromatogr. 1983, 260, 241.

23. Moritani, T.; Yoon, K.; Rafailovich, M.; Chu, B.; Electrophoresis 2003, 24, 2764.

24. Du, M.; Flanagan, J. H.; Lin, B.; Ma, Y. F.; Electrophoresis 2003, 24, 3147.

25. Catai, J. R.; Carrilho, E.; J. Braz. Chem. Soc. 2004, 15, 413.

26. Assunção, N. A.; Deziderio, L. A. G.; Paulino, L. G.; Lupetti, K. O.; Carrilho, E.; Electrophoresis 2005, 26, 3292.
27. Caruso, C. S.; Lanças, F. M.; Carrilho, E.; Electrophoresis 2003, 24,78 .

28. Song, L.; Liang, D.; Fang, D.; Chu, B.; Electrophoresis 2001, 22, 1987.

29. Butker, J. M.; McCord, B. R.; Jung, J. M.; Allen, R. O.; Biotechniques 1994, 17, 1062.

30. Rampal, S.; Liu, M.; Chen, F.; J. Chromatogr. A 1997, 781, 357.

31. Wang, Y.; Jingyue, J.; Carpenter, B. A.; Atherton, J. M.; Sensabaugh, G. F.; Mathies, R. A.; Anal. Chem. 1995, 67, 1197.

32. Zhu, H.; Steven, M. C.; Benson, S. C.; Rye, H. S.; Glazer, A. N.; Mathies, R. A.; Anal. Biochem. 1994, 66, 1941.

33. Hung, S., Ju, J.; Mathies, R. A.; Glazer, A. N.; Anal. Biochem. 1996, 243, 15.

34. Wan, H.; Ohman, M.; Blomberg, L. G., J. Chromatogr. 2001, $924,59$.

Received: December 15, 2008

Web Release Date: October 29, 2009

FAPESP helped in meeting the publication costs of this article. 